\title{
Feeding of palm oil fatty acids or rapeseed oil throughout lactation: Effects on energy status, body composition, and milk production in Norwegian dairy goats
}

\author{
M. Eknæs, ${ }^{* 1}$ Y. Chilliard,† K. Hove, ${ }^{*}$ R. A. Inglingstad,‡ L. Bernard, $†$ and H. Volden* \\ *Faculty of Biosciences (BIOVIT), Norwegian University of Life Sciences (NMBU), 1430 Ås, Norway \\ †UMR1213 Herbivores, Institut National de la Recherche Agronomique (INRA)-Clermont-Theix-Lyon, F-63122 Saint-Genès-Champanelle, France \\ ‡Faculty of Chemistry, Biotechnology and Food Science (KBM), Norwegian University of Life Sciences (NMBU), 1430 Ås, Norway
}

\begin{abstract}
The objective of this experiment was to examine how supplements of rapeseed oil or palm oil fatty acids would affect milk production and composition, body lipid stores, and energy balance in 30 multiparous goats of Norwegian dairy goat breed. The experiment lasted $230 \mathrm{~d}$, with 1 to $120 \mathrm{~d}$ in milk (DIM) for indoor feeding (P1), 120 to 200 DIM for mountain grazing (P2), and 200 to 230 DIM for indoor feeding (P3). Grass silage was fed according to appetite during indoor feeding periods. After an adjustment period (1-60 DIM) when the control diet was given to the goats, the animals were subdivided into 3 groups of 10 goats. Treatments (60-230 DIM) were (1) basal concentrate (control; no added fat); (2) control concentrate with $8 \%$ (added on air-dry basis) hydrogenated palm oil enriched with palmitic acid (POFA); and (3) control concentrate with $8 \%$ (added on air-dry basis) rapeseed oil (RSO). Individual energy balances based on energy intake and milk production were estimated on 10, 30, 60, 90, 120, 200, and 230 DIM. At the same times, body weight (BW), body condition score (BCS), body mass index, and body tissue stores using computed tomography were monitored. Silage intake was depressed by POFA throughout the experimental period. Reduced BW and body mass index were observed in the POFA and RSO groups, whereas no effect on BCS or body composition was observed throughout lactation. Generally, a minor decrease in BW was observed from 10 to 120 DIM (only $0.6 \mathrm{~kg}$ on average) and the total amount of body lipid was reduced by $4.4 \mathrm{~kg}$. During the mountain grazing period, a further reduction in body lipid stores $(2.7$ $\mathrm{kg}$ ) was observed, and BW was reduced by $3.9 \mathrm{~kg}$ in the same period. The goats mobilized, on average, $72 \%$
\end{abstract}

Received March 20, 2017.

Accepted May 22, 2017.

${ }^{1}$ Corresponding author: margrete.eknas@nmbu.no of their fat reserves during the first 200 DIM. In this period, dietary fat supplementation did not reduce the mobilization of adipose tissue but resulted in greater milk fat yield (2 kg more, on average, compared with the control group). Milk yield was not affected by POFA or RSO supplementation. Milk fat content was higher in the POFA group than in the control and RSO groups. Milk protein and lactose contents were not affected by lipid supplements. In late lactation, a rapid accumulation of fat deposits followed the intense mobilization during the grazing period. Dietary lipid supplements had no effect on milk fat yield at this stage. Milk production depends heavily on the ability to mobilize body lipid stores, and neither POFA nor RSO supplements at rates used in our study affected this mobilization.

Key words: goat milk production, palm oil, rapeseed oil, energy status, adipose tissue mobilization

\section{INTRODUCTION}

Over the last $15 \mathrm{yr}$, a rapid structural development has taken place in Norwegian dairy goat farming, which has resulted in larger farm units, in which average yields per animal increased from 560 to $725 \mathrm{~kg} / \mathrm{yr}$. The total volume of goat milk delivered to the market has not changed, however.

Dry matter intake and ingested energy and nutrients are the main factors influencing milk yield and composition (Morand-Fehr et al., 2007). In high-yielding cows, dietary lipid supplementation can be a practical tool to increase energy intake in early lactation (Chilliard, 1993). Fatty acids derived from calcium salts of palm oil are commonly used for dairy energy supplementation (Onetti and Grummer, 2004; Rabiee et al., 2012). Feeding trials with calcium salts of palm oil fatty acids in dairy goats are scarce. When calcium salts of palm oil fatty acids were added to the diet of Alpine goats at rates of $0,3,6$, and $9 \%$, Teh et al. (1994) observed that milk yield and BW gain decreased linearly with the rate of inclusion, whereas milk fat content increased. Otaru et al. (2011) reported that an addition of $4 \%$ 
palm oil in concentrate increased daily milk production by $29 \%$ and did not affect BW of low-yielding Red Sokoto goats.

Palm oil is rich in palmitic acid (C16:0), and leads to elevated milk palmitic acid concentrations, which is considered unfavorable in human nutrition (Shingfield et al., 2008). Conversely, plant oils rich in PUFA can be used to obtain beneficial changes in milk fat composition by a reduction in fatty acids synthesized de novo (C10:0 to C16:0) and an increase in C18:0, C18:1 cis-9, CLA cis-9,trans-11, and n-3 PUFA in cows and goats (Chilliard et al., 2003; Bernard et al., 2009a).

Among Norwegian plant fat resources, rapeseed is a promising feed supplement, which could improve both the milk sensory properties and nutritional quality through its fatty acid composition, in addition to sustaining a production relying on national resources. Indeed, previous studies in goats have shown that feeding rapeseed reduces milk lipoprotein lipase (LPL) activity and the level of free fatty acids, decreases milk short- and medium-chain SFA, and increases C18:0 and C18:1 cis-9 (Ollier et al., 2009). Supplements of rapeseed oil to Norwegian goats resulted in lower free fatty acid content and better milk taste compared with the control group or a group fed palm oil-derived fatty acid supplementation (Inglingstad et al., 2017).

The objective of the present study was to examine how supplementation of rapeseed oil (rich in long-chain UFA) or palm oil-derived fatty acids (rich in SFA) would affect milk production and composition, body lipid stores and energy status in dairy goats. We hypothesize, therefore, that rapeseed oil in the diet will improve energy status and milk production in dairy goats.

\section{MATERIALS AND METHODS}

\section{Experimental Design}

The experiment was carried out at the Norwegian University of Life Sciences, Department of Animal and Aquaculture Sciences, Ås, in agreement with the laws and regulations controlling experiments on live animals in Norway and under the supervision of the Norwegian Animal Research Authority.

The experiment included 30 goats of the Norwegian dairy goat breed in second to fourth lactation, kidding from February 3 to March 7. Average BW 2 d after kidding was $54.4 \pm 6.7 \mathrm{~kg}$.

The experiment had a continuous design, lasted for $230 \mathrm{~d}$ and consisted of 3 periods with 1-120 DIM for indoor feeding (P1), 120-200 DIM for mountain grazing (P2), and 200-230 DIM for indoor feeding (P3). In the first half of P1, called the preparatory period (1-60 DIM), all goats were fed a basal concentrate without added fat (control). Thereafter, the goats were allocated to 3 groups, each of 10 goats, based on age, date of kidding, BW, milk yield, and genotype [homozygous (E12-00; homozygous for a deletion in exon 12 of the gene encoding $\alpha_{S_{1}} \mathrm{CN}, C S N 1 S 1$, which causes low or no synthesis of $\alpha_{\mathrm{SI}^{-}} \mathrm{CN}$ in their milk) or heterozygous (E12-01; goats with only one deletion in exon 12 of CSN1S1)]. In addition to low or no expression of $\alpha_{S_{1}-}$ $\mathrm{CN}$ in the milk, this deletion correlates with reduced contents of protein, fat, and lactose and increased milk yield (Dagnachew et al., 2011). Each group consisted of 7 goats heterozygous (E12-01) for the deletion in exon 12 at the $\alpha_{\mathrm{S} 1}-\mathrm{CN}$ locus, and 3 were homozygous (E12-00) for this deletion.

\section{Experimental Concentrates}

The 3 experimental concentrates (and corresponding experimental groups) were (1) control concentrate $(\mathbf{C O N}) ;(2)$ control concentrate with $8 \%$ (added on an air-dry basis) hydrogenated palm oil fatty acids enriched with palmitic acid (Akofeed Gigant 60, AarshusKarlshamn Sweden AB, Karlshamn, Sweden; POFA); and (3) control concentrate with $8 \%$ (added on an air-dry basis) rapeseed oil (AarshusKarlshamn Sweden AB; RSO). The experimental concentrates (Table 1), were produced by Centre for Feed Technology at the Norwegian University of Life Sciences.

Table 1. Composition $(\mathrm{g} / \mathrm{kg})$ of the 3 experimental concentrates

\begin{tabular}{|c|c|c|c|}
\hline \multirow[b]{2}{*}{ Ingredient } & \multicolumn{3}{|c|}{ Treatment $^{1}$} \\
\hline & $\mathrm{CON}$ & POFA & $\mathrm{RSO}$ \\
\hline Barley & 540 & 460 & 460 \\
\hline Rapeseed meal, Expro 00SF ${ }^{2}$ & 90 & 90 & 90 \\
\hline Soybean, extracted & 160 & 180 & 180 \\
\hline Beet pulp, unmolassed & 120 & 100 & 100 \\
\hline Molasses & 50 & 50 & 50 \\
\hline Akofeed Gigant 60 vegetable fat ${ }^{3}$ & - & 80 & - \\
\hline Rapeseed oil $^{4}$ & - & - & 80 \\
\hline Mineral and vitamin premix & 40 & 40 & 40 \\
\hline
\end{tabular}

${ }^{1} \mathrm{CON}=$ basal diet containing no additional fat; POFA = basal diet supplemented with hydrogenated palm oil enriched with palmitic acid; $\mathrm{RSO}=$ basal diet supplemented with rapeseed oil.

${ }^{2}$ Rapeseed meal, Expro 00SF (AarhusKarlshamn Sweden AB, Karlshamn, Sweden).

${ }^{3}$ Akofeed Gigant 60 (AarhusKarlshamn Sweden AB) contained (g/kg of total FA): C14:0 (20), C16:0 (minimum 600), C18:0 (maximum 270), C18:1 (100), C18:2 (10).

${ }^{4}$ Rapeseed oil (AarhusKarlshamn Sweden AB) contained (g/kg of total FA): C16:0 (45), C18:0 (15), C18:1 (620), C18:2 (205), C18:3 (85), C22:1 (10), others (30). 


\section{Animal Management}

During the spring and autumn indoor feeding periods, goats were kept in individual stalls at the experimental farm at $\AA$ s $\left(59^{\circ} 39^{\prime} \mathrm{N} ; 10^{\circ} 46^{\prime} \mathrm{E} ; 90 \mathrm{~m}\right.$ above sea level) and fed grass silage according to appetite (10\% refusals). The silage crop was harvested from the primary growth on June 16 and consisted of timothy (Phleum pratense L.), meadow fescue (Festuca pratensis Huds.), and red clover (Trifolium pratense L.). After cutting, the grass was wilted for 1 to $10 \mathrm{~h}$ during daytime or for 16 to $20 \mathrm{~h}$ overnight to achieve a target DM content of 250 $\mathrm{g} / \mathrm{kg}$ of DM. The grass was baled using an Orkel HiQ (Orkel AS, Fannrem, Norway) roundbaler, and preserved with an acidic additive, Ensil1 (Felleskjøpet Agri SA, Lillestrøm, Norway), applied at a rate of $4 \mathrm{~L} / \mathrm{t}$. The bales were wrapped in 6 layers of 0.025 -mm-thick white plastic film (Trio Wrap, Trioplast AB, Sweden). Mountain pastures were located in Folldal $\left(62^{\circ} 19^{\prime} \mathrm{N}\right.$; $10^{\circ} 1^{\prime} \mathrm{E}$; above the treeline, 900 to $1,000 \mathrm{~m}$ above sea level) and consisted of marsh areas with sedges (mainly Carex nigra and Carex rostrata) and drier areas with grasses (mainly Deschampsia cespitosa and Deschampsia flexuosa), willow thickets (Salix spp.), birch (Betula spp.), and a variety of herbs. The goats grazed freely day and night.

Concentrates were given at a rate of $0.9 \mathrm{~kg} / \mathrm{d}$ during $\mathrm{P} 1$ and $0.7 \mathrm{~kg} / \mathrm{d}$ during P2 and P3. The daily concentrate ration was divided into 3 equal meals during $\mathrm{P} 1$ and P3 and into 2 equal meals during P2. The goats were milked in a milking stable twice a day at 0630 and $1600 \mathrm{~h}$. The goats were mated during P3.

\section{Computer Tomography}

Tissue mass was determined by computerized x-ray tomography (CT) as described by Eknæs et al. (2006). The CT scans were taken at 10,30,60, 90, 120, 200, and 230 DIM. The goats were fasted for a minimum of $16 \mathrm{~h}$ before scanning. To minimize movements, xylazine $(0.1 \mathrm{mg} / \mathrm{kg}$ of BW) was given intravenously. A total of 25 to 30 cross-sectional images, taken at a distance of $40 \mathrm{~mm}$, between the hock joint and the first cervical vertebra were collected from each animal. Scans were retaken whenever animal movements resulted in poor image quality.

The soft tissues measured by CT were protein-rich tissue (mainly muscle), visceral adipose tissue (AT), carcass AT (subcutaneous, inter- and intramuscular fat) and nonfat visceral components (i.e., rumen, large intestine). By means of a light pen and computer software, the nonfat visceral components were delineated and removed from the CT images. A PC-based CT image analysis program (in house Matlab script) was used to quantify the areas of the tissue categories. Tissue mass was estimated from total tissue volume and mean tissue density. Total volume was determined using Cavalieri's principle by multiplying the sum of areas in all images with the distance between each image, assuming a random sampling of parallel sections separated by a distance of $40 \mathrm{~mm}$ (Gundersen et al., 1988). Mean density was determined from a function relating Hounsfield unit value to tissue densities (Fullerton, 1980):

$$
\text { Tissue density }=1.0062
$$

$+($ mean tissue Hounsfield unit value $\times 0.00601)$.

Using this calculation method, the carcass fat, visceral fat, total AT (sum of carcass and visceral fat), proteinous tissue, and bone tissue were determined.

\section{Registrations and Samplings}

Silage intake was measured on 3 consecutive days each week during P1 and P3. Milk yield was measured on 3 subsequent days every second week during P1 and P3 and on 2 subsequent days every fourth week during $\mathrm{P} 2$. The goats were first weighed $2 \mathrm{~d}$ after kidding. Then, BW was recorded over 3 consecutive days starting at 10,30,60, 90, 120, 200, and 230 DIM. Body mass index [BMI; BW $(\mathrm{kg}) /$ neck height $(\mathrm{m}) \times$ body length $(\mathrm{m})$ ] was measured as described by Tanaka et al. (2002), and BCS was determined by a panel of 2 people, using a scale from 1 to 5 with 0.25 -point increments, as described by Ngwa et al. (2007). Body mass index and BCS were determined over 2 consecutive days at 10, 30, $60,90,120,200$, and 230 DIM in connection with the BW measurements.

Milk was sampled 6 times throughout the lactation period, at 30, 60, 90, 120, 190, and 230 DIM. Milk samples consisted of a mixture of evening and morning milk. Morning and evening milk samples were pooled in the ratio $1.5: 1$, according to the estimated average ratio between morning and evening milk. Pooled samples were conserved with one tablet of Bronopol (2-bromo2-nitropropane-1,3-diol; D\&F Control Systems Inc., Dublin, CA) and stored at $4^{\circ} \mathrm{C}$ for $84 \mathrm{~h}$ before analysis.

\section{Chemical Analysis}

Silage samples were collected in connection with feed intake measurements, and stored at $-20^{\circ} \mathrm{C}$ until analyzed. Weekly pooled samples were dried at $<60^{\circ} \mathrm{C}$ to constant weight and weighed warm to obtain DM concentration. Subsequently, samples were adjusted to room temperature and humidity. The silage samples were milled on a Retsch Impeller-type Cutting Mill SM 
1 (Retsch GmbH \& Co. KG, Haan, Germany) to pass a 1.0-mm screen and pooled into 4 silage samples in P1 and into 1 silage sample in P3.

The composited silage samples were analyzed for DM and ash as described by Malkomesius and Nehring (1951). Kjeldahl-N was determined according to AOAC International (2000; method 984.13). Crude protein was expressed as $\mathrm{N} \times 6.25$. Neutral detergent fiber inclusive ash (aNDF) was determined using sodium sulfite and heat-stable amylase according to Van Soest et al. (1991). Crude fat was determined after hydrolysis of the samples with $3 \mathrm{M} \mathrm{HCl}$, extraction with petroleum ether, and then distillation of the eluent followed by drying and weighing the residues. Total $\mathrm{N}$ was determined by combustion using an EA 1108 Elementar Analyzer (Fison, Säntis Analytical Scandinavia AB, Uppsala, Sweden) according to the method described by Kirsten and Hesselius (1983).

After pooling subsamples collected at intervals during the experimental period, 1 composite sample of each concentrate feed was analyzed for ash, Kjeldahl$\mathrm{N}$, aNDF, crude fat, and total $\mathrm{N}$ as described above. Content of DM was determined by drying for $4 \mathrm{~h}$ at $103^{\circ} \mathrm{C}$ and starch was determined by an enzymatic method ( $\alpha$-amylase and amyloglucosidase; Megazyme, Wicklow, Ireland).

Fatty acid composition in silages and concentrates were measured by GC (Vitas AS, Oslo, Norway). Two hundred milligrams of dried and milled samples was transferred to soda lime tubes, and methyl tricosanoate (Nu-Chek Prep, Elysian, MN), as an internal standard, and $3 \mathrm{~N}$ methanolic $\mathrm{HCl}$ were added. After $2 \mathrm{~h}$ of methylation at $80^{\circ} \mathrm{C}, 100 \mu \mathrm{L}$ was transferred to a $\mathrm{GC}$ vial, diluted with hexane, and separated on an Agilent 7890A Gas Chromatograph System with flame-ionization detector (Agilent Technologies, Palo Alto, CA). The fatty acids were separated on a Supelcowax $(30 \mathrm{~m} \times 250 \mu \mathrm{m}$ $\times 0.2 \mu \mathrm{m}$; Supelco Inc., Bellefont, PA) column. The $\mathrm{GC}$ oven temperature was $70^{\circ} \mathrm{C}$ for $0.5 \mathrm{~min}$, raised by $30^{\circ} \mathrm{C} / \mathrm{min}$ to $170^{\circ} \mathrm{C}$, and then by $1.5^{\circ} \mathrm{C} / \mathrm{min}$ to $221^{\circ} \mathrm{C}$, and finally by $50^{\circ} \mathrm{C} / \mathrm{min}$ to $255^{\circ} \mathrm{C}$ for $5 \mathrm{~min}$.

Milk samples were analyzed for fat, protein, lactose, and SCC by FTIR/MilkoScan (MilkoScan Combifoss 6500; Foss, Hillerød, Denmark).

\section{Statistical Analysis}

Analysis of variance was performed using the MIXED procedure (Littell et al., 1998) of SAS (version 9.4, SAS Institute Inc., Cary, NC). All measurements were repeated 7 times for each animal and appeared correlated. Consequently, these correlations were taken into account in the statistical model. Covariance structure of the repeated measurements was chosen by compar- ing potential structures using Akaike's and Schwarz's Bayesian information criterion (Wolfinger, 1996), and a spatial power covariance structure proved useful for all data. The value at 60 DIM was used as a covariate. The repeated-measures ANOVA was performed according to the following model:

$$
\begin{aligned}
\mathrm{Y}_{i j k l} & =\mu+A_{i}+B_{j}+A \times B_{(i j)}+C_{k} \\
& +A \times C_{(i k)}+d\left(A_{i} C_{k}\right)+\varepsilon_{i j k l},
\end{aligned}
$$

where $Y_{i j k l}$ is the dependent variable; $\mu$ is the intercept; $A_{i}$ is the fixed effect of concentrate type, $i=1,2,3$ (CON, POFA, RSO); $B_{j}$ is the fixed effect of DIM, $j=$ $1,2, \ldots, 4$ (DIM 90, 120, 190/200, 230); $A \times B_{(i j)}$ is the interaction between concentrate type $i$ and DIM $j ; C_{k}$ is the fixed effect of genotype at the CSN1S1 locus, $k$ $=1,2(\mathrm{E} 12-00, \mathrm{E} 12-01) ; A \times C_{(i k)}$ is the interaction between concentrate type $i$ and genotype $k ; d\left(A_{i} C_{k}\right)$ is random effect of goat within concentrate type $i$ and genotype $k$; and $\varepsilon_{i j k l}$ represents the experimental error.

Differences between means were tested based on least square differences using the default pairwise $t$-test in the pdiff option in the lsmeans statement. Differences were considered statistically significant when $P<0.05$, and trends were apparent when $0.05 \leq P<0.10$.

\section{RESULTS}

\section{Nutritive Characteristics and Feed Intake}

The chemical composition of the experimental concentrates and silage is presented in Table 2. The DM content of the concentrate mixtures were 912,889 , and $897 \mathrm{~g} / \mathrm{kg}$ for CON, POFA, and RSO, respectively. The concentrate mixtures were iso-nitrogenous with $190 \mathrm{~g}$ of $\mathrm{CP} / \mathrm{kg}$ of DM. The contents of crude fat in the POFA and RSO concentrates were almost identical, 107 and $110 \mathrm{~g} / \mathrm{kg}$ of DM, respectively, whereas the CON concentrate contained only $22 \mathrm{~g}$ of crude fat $/ \mathrm{kg}$ of DM. The estimated energy contents of the POFA and RSO concentrates were identical (8.21 MJ of $\mathrm{NE}_{\mathrm{L}} / \mathrm{kg}$ of DM) and higher than that of the CON concentrate (7.52 MJ of $\mathrm{NE}_{\mathrm{L}} / \mathrm{kg}$ of $\mathrm{DM}$ ).

The formulation of the concentrates resulted in expected high concentrations of C16:0 and C18:0 (total of $84 \mathrm{~g} / \mathrm{kg}$ of DM) in the POFA diet and high concentrations of C18:1 cis-9, C18:2, and C18:3 (total of $86 \mathrm{~g} / \mathrm{kg}$ of DM) in the RSO diet (Table 3). All goats consumed their concentrates without orts.

Silage intake was depressed in the group fed POFA concentrate throughout the experimental period (Figure 1). After the mountain grazing period, silage intake increased in all groups, but intake by the POFA group 
Table 2. Chemical composition ( $\mathrm{g} / \mathrm{kg}$ of DM unless otherwise noted) of silage and experimental concentrates

\begin{tabular}{|c|c|c|c|c|}
\hline \multirow{2}{*}{$\begin{array}{l}\text { Chemical } \\
\text { composition }\end{array}$} & \multicolumn{3}{|c|}{ Treatment $^{1}$} & \multirow[b]{2}{*}{ Silage } \\
\hline & $\mathrm{CON}$ & POFA & $\mathrm{RSO}$ & \\
\hline $\mathrm{DM}, \mathrm{g} / \mathrm{kg}$ & 912 & 889 & 897 & 253 \\
\hline $\mathrm{CP}$ & 196 & 191 & 195 & 138 \\
\hline Crude fat & 22 & 107 & 110 & 34 \\
\hline Starch & 343 & 280 & 299 & \\
\hline $\mathrm{aNDF}^{2}$ & 187 & 172 & 168 & 531 \\
\hline Total N & 32.5 & 34.5 & 34.9 & 23.4 \\
\hline Ash & 73.0 & 72.5 & 69.5 & 77.2 \\
\hline $\mathrm{NE}_{\mathrm{L}}, \mathrm{MJ} / \mathrm{kg}$ of $\mathrm{DM}$ & $7.52^{3}$ & $8.21^{3}$ & $8.21^{3}$ & 6.07 \\
\hline
\end{tabular}

${ }^{1} \mathrm{CON}=$ basal concentrate containing no additional fat; POFA = basal concentrate supplemented with hydrogenated palm oil enriched with palmitic acid; RSO = basal concentrate supplemented with rapeseed oil.

${ }^{2} \mathrm{NDF}$ assayed with $\alpha$-amylase and expressed exclusive of residual ash.

${ }^{3}$ Based on calculated values.

was still lower than that in the CON and RSO groups. Depressed silage intake in the POFA group resulted in a lower $(P<0.01)$ forage:concentrate ratio and a lower $(P<0.05)$ energy balance compared with $\mathrm{CON}$ and RSO (Table 4).

\section{$B W, B C S$, and $B M I$}

The goats lost BW rapidly from kidding to 10 DIM and then between 60 and 90 DIM and during the mountain pasture period (Tables 4 and 5). During the autumn indoor feeding period (200-230 DIM), the goats'
Table 3. Fatty acid composition (g of fatty acids $/ \mathrm{kg}$ of $\mathrm{DM}$ ) of concentrates and silage

\begin{tabular}{lrrrr}
\hline & \multicolumn{3}{c}{ Treatment $^{1}$} \\
\cline { 2 - 3 } Fatty acid & CON & POFA & RSO & Silage \\
\hline C14:0 & 0.1 & 0.8 & 0.1 & 0.2 \\
C16:0 & 3.9 & 56.4 & 8.9 & 4.5 \\
C16:1 cis-9 & 0.1 & 0.1 & 0.3 & 0.5 \\
C18:0 & 0.4 & 27.8 & 2.6 & 0.5 \\
C18:1 cis-9 & 3.3 & 4.8 & 53.7 & 1.1 \\
C18:1 cis-11 & 0.5 & 0.8 & 3.4 & 0.2 \\
C18:2n-6 & 8.2 & 8.6 & 25.1 & 5.1 \\
C18:3n-3 & 1.0 & 1.1 & 7.6 & 14.0 \\
C20:0 & 0.0 & 0.3 & 0.7 & 0.3 \\
\hline
\end{tabular}

${ }^{1} \mathrm{CON}=$ basal concentrate containing no additional fat; POFA $=$ basal concentrate supplemented with hydrogenated palm oil enriched with palmitic acid; RSO = basal concentrate supplemented with rapeseed oil.

BW increased by $7.3 \mathrm{~kg}$ on average, corresponding to a BW gain of $257 \mathrm{~g} / \mathrm{d}$ (Tables 4 and 5 ).

Body condition score decreased slightly during the first month of lactation (Table 4). From 90 to 200 DIM, BCS was nearly constant and was not affected by lipid supplements. During the autumn indoor feeding period (P3), the BCS in the lipid-supplemented goats improved slightly $(P<0.05)$, whereas no difference was observed for CON goats.

Body mass index did not change during early lactation. At 90 DIM, no differences in BMI between groups were observed. From 120 DIM and throughout the experiment, the CON group had a higher BMI than the

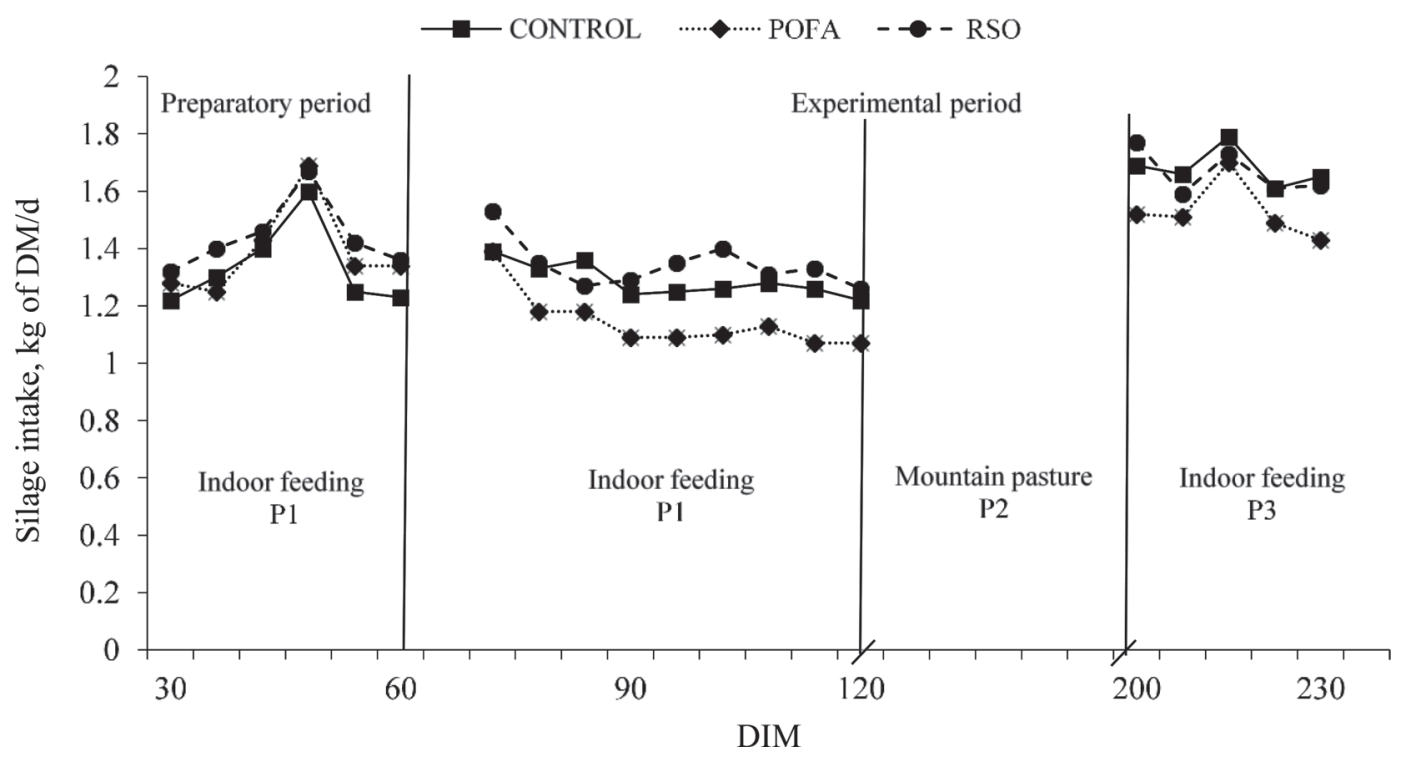

Figure 1. Silage DMI measured throughout the lactation in goats receiving different lipid supplemented concentrates from 61 to 230 DIM. Control = basal concentrate containing no additional fat; POFA = basal concentrate supplemented with hydrogenated palm oil enriched with palmitic acid; RSO = basal concentrate supplemented with rapeseed oil. All values are means. 
LIPIDS AND ENERGY STATUS IN DAIRY GOATS

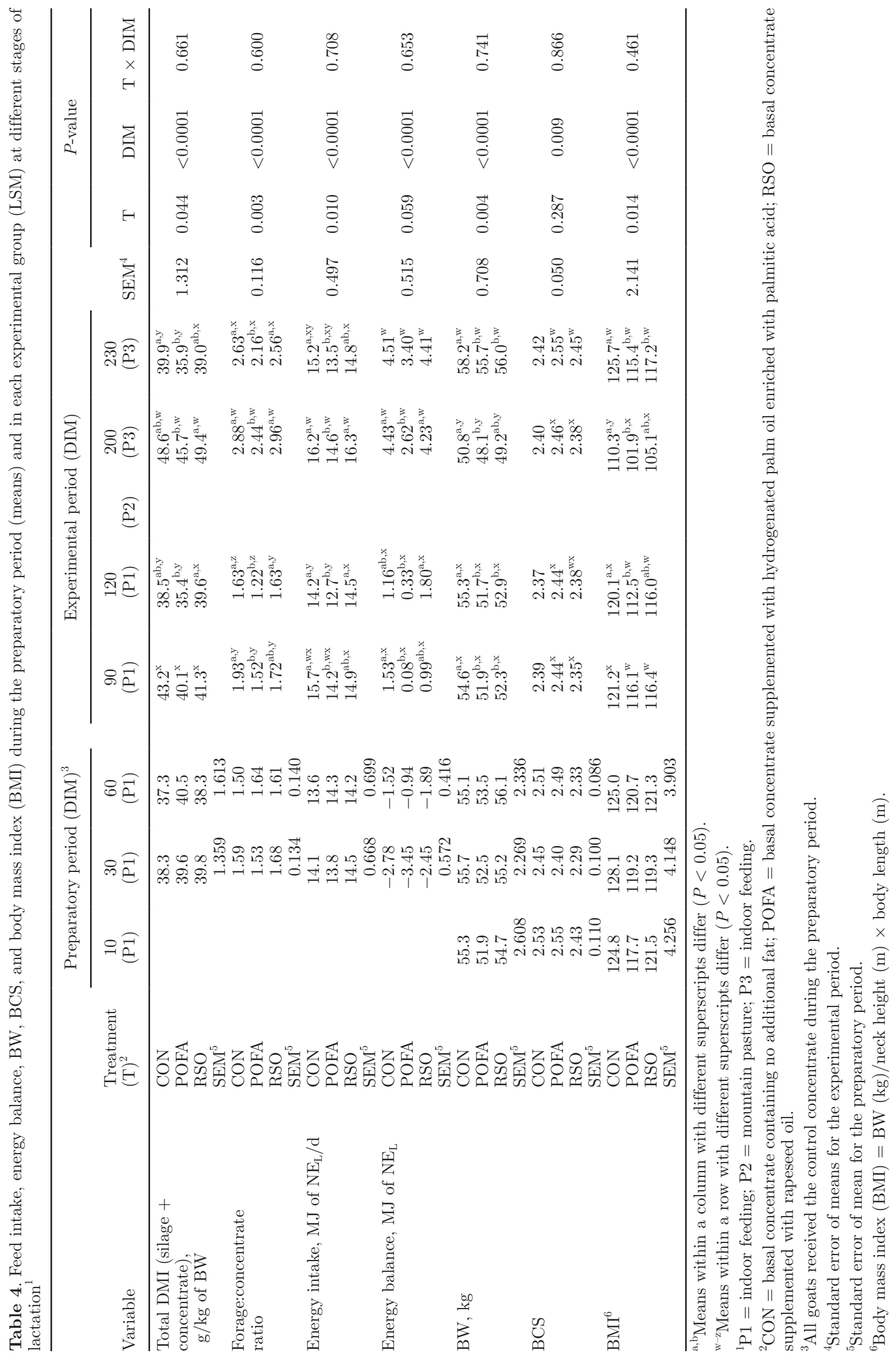




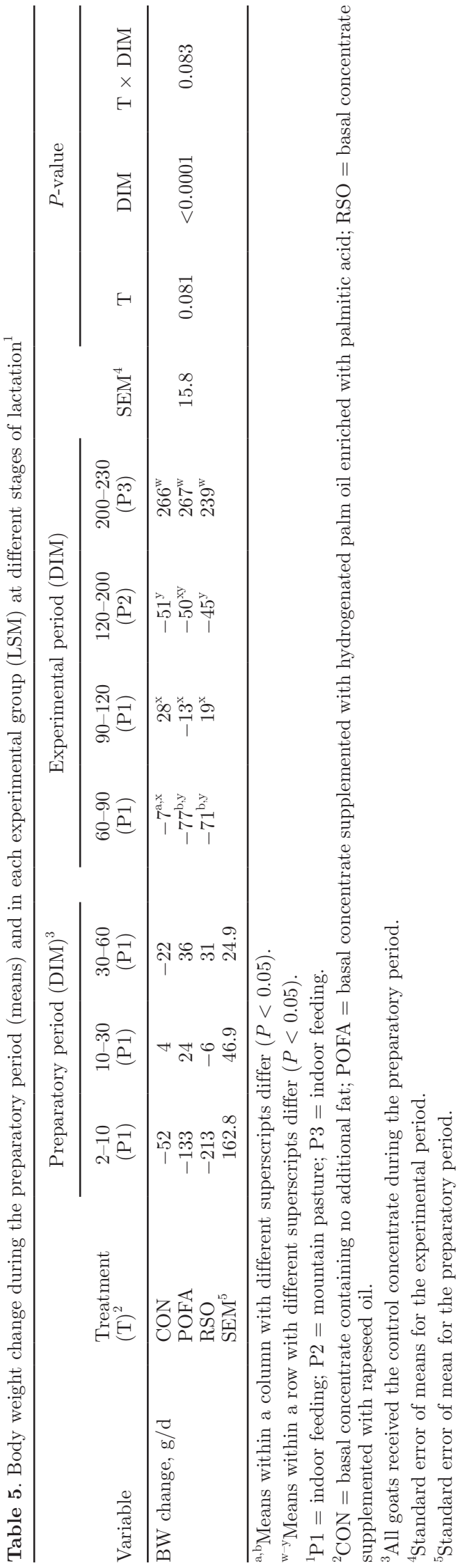

POFA group but outperformed the RSO group only at 230 DIM (Table 4).

\section{Body Tissue Mass Changes}

Provision of dietary lipids at the rates used did not affect amounts of body tissues, except at 230 DIM when the POFA group had more visceral $(P=0.036)$ and total body lipid $(P=0.034)$ compared with the CON group (Table 6). The rate of body lipid mobilization was highest from 10 to 30 DIM, on average $101 \mathrm{~g} / \mathrm{d}$ (Figure 2). In this period, the goats also mobilized an average of $28 \mathrm{~g} / \mathrm{d}$ of proteinous tissue. From 90 to 120 DIM, the goats neither mobilized nor deposited body lipid. The CT measurements correspond to the shift from negative to positive energy balance between 60 and 90 DIM. During the mountain grazing period, the goats again underwent a pronounced body lipid mobilization, and at 200 DIM, the total amount of body lipid measured by CT was reduced to $28 \%$ of the amount at 10 DIM. During the autumn indoor feeding period (200-230 DIM), the goats rebuilt their body lipid resources with a depot of $92 \mathrm{~g} / \mathrm{d}$ on average. Despite this, the ratio between $\mathrm{AT}$ and proteinous tissue mass remained much lower compared with the ratio at 10 DIM, indicating that further rebuilding of body lipid would be required to regain body reserves before next parturition. Differential rate of mobilization of lipids from the carcass and visceral depots was observed during the first $60 \mathrm{~d}$ of lactation, with preferred release of fat from the visceral reserves (Figure 3).

\section{Milk Production}

Milk yield was not affected by lipid supplements, except in the mountain grazing period when production of ECM was higher $(+0.3 \mathrm{~kg} / \mathrm{d} ; P<0.05)$ in the lipidsupplemented groups compared with the CON group (Table 7).

During the experimental period (90 to 230 DIM), the milk fat content was higher in POFA goats than in the CON $(P<0.001)$ and RSO $(P<0.05)$ goats. At 90 DIM, daily milk fat yield was higher $(P<0.01)$ in POFA than in CON goats, whereas no difference was observed between the 2 dietary lipid sources. At the end of the mountain grazing period (190 DIM), the CON goats had lower milk fat yield than the POFA $(P$ $<0.01)$ and RSO goats $(P<0.05)$. At 230 DIM, milk fat yield was low in all 3 groups and no difference was observed between groups (Table 7).

Milk protein yield gradually decreased from 30 DIM and throughout lactation until 230 DIM, whereas protein content decreased from 10 to 120 DIM, increased during P2, and then decreased again during P3 in all 
LIPIDS AND ENERGY STATUS IN DAIRY GOATS

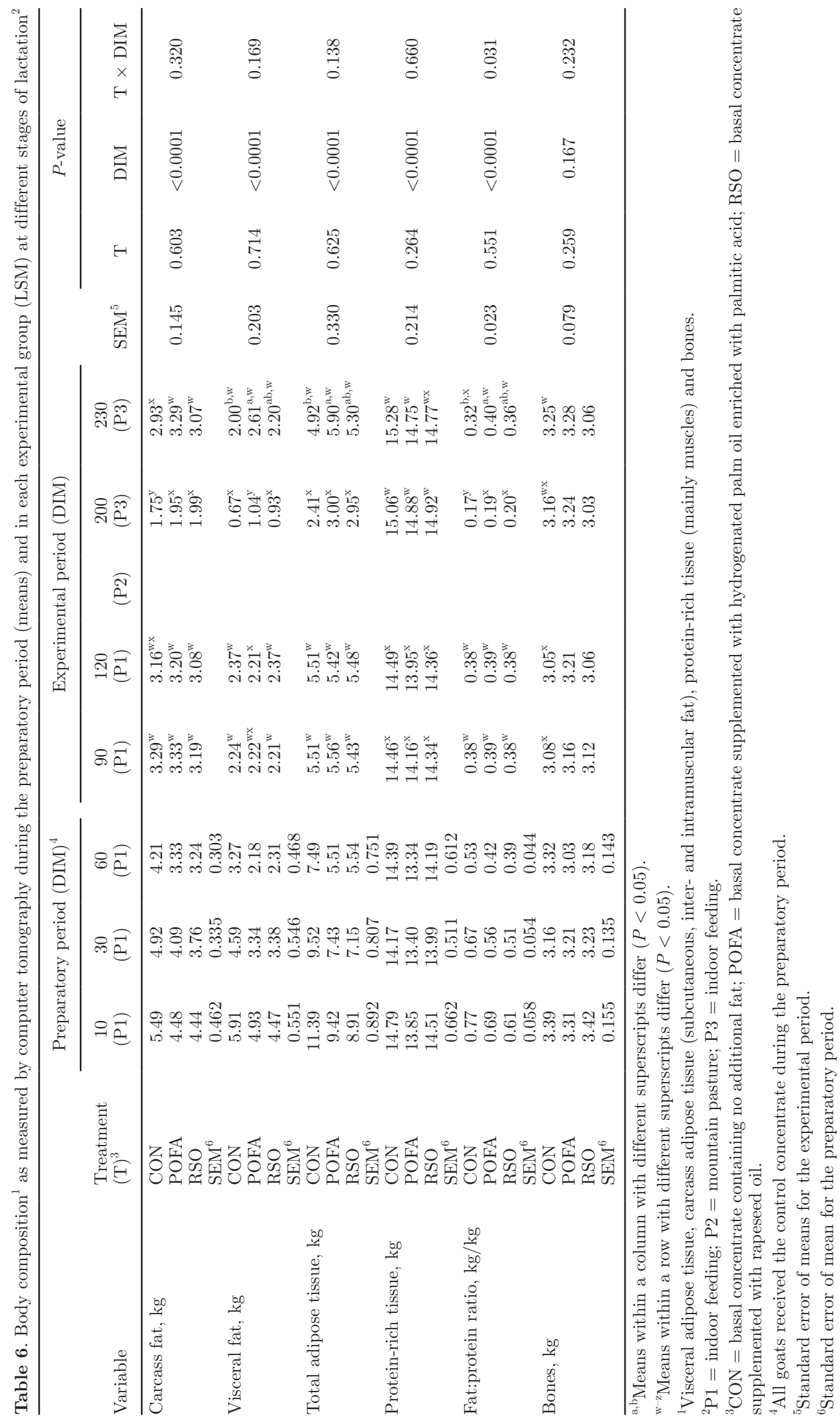




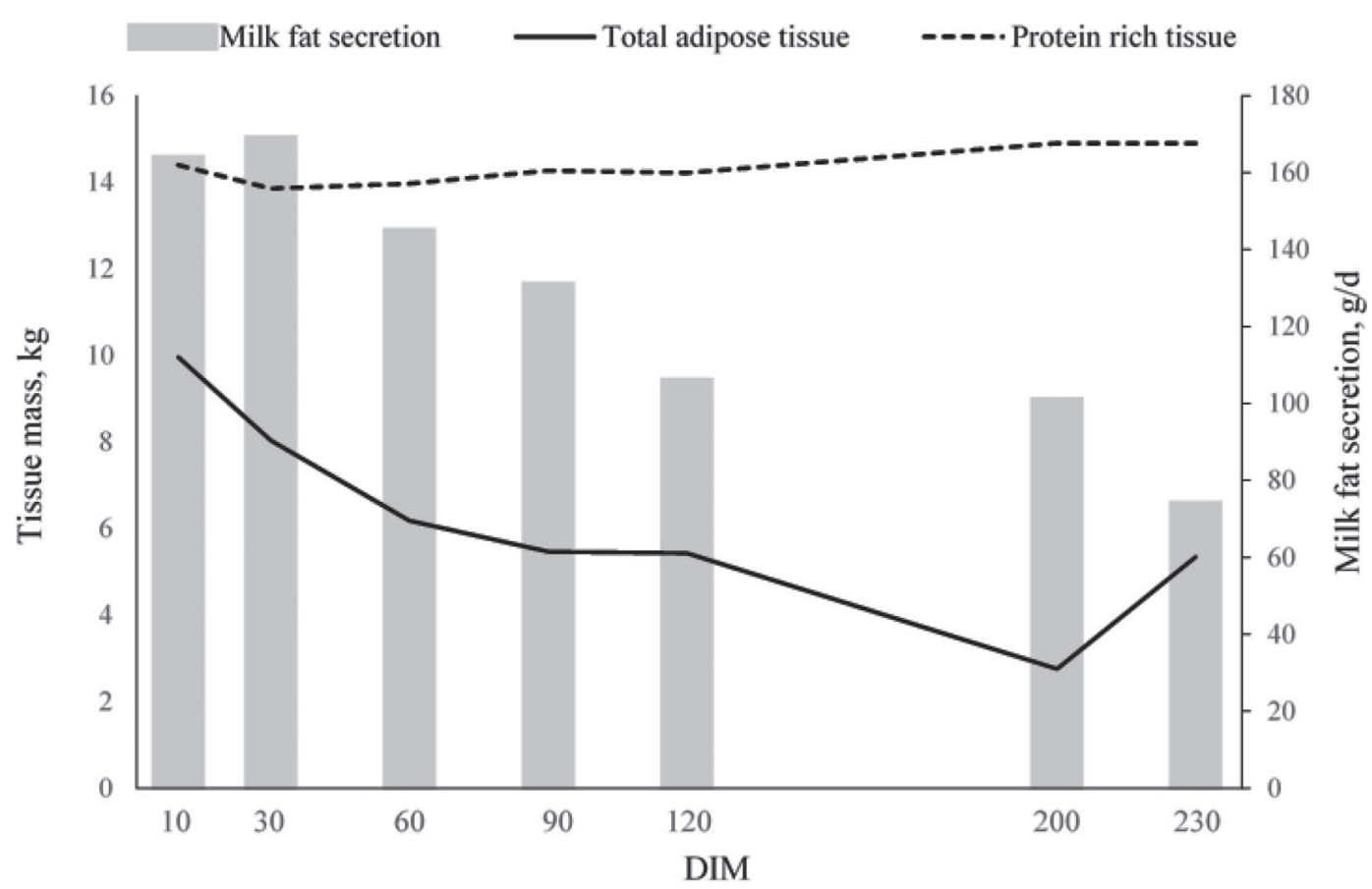

Figure 2. Changes in the mass of adipose and protein-rich tissues in relation to milk fat secretion throughout a lactation. Values are averages for all the experimental goats, irrespective of feeding group. Values at 10, 30, and 60 DIM are means; values at 90 to 230 DIM are LSM.

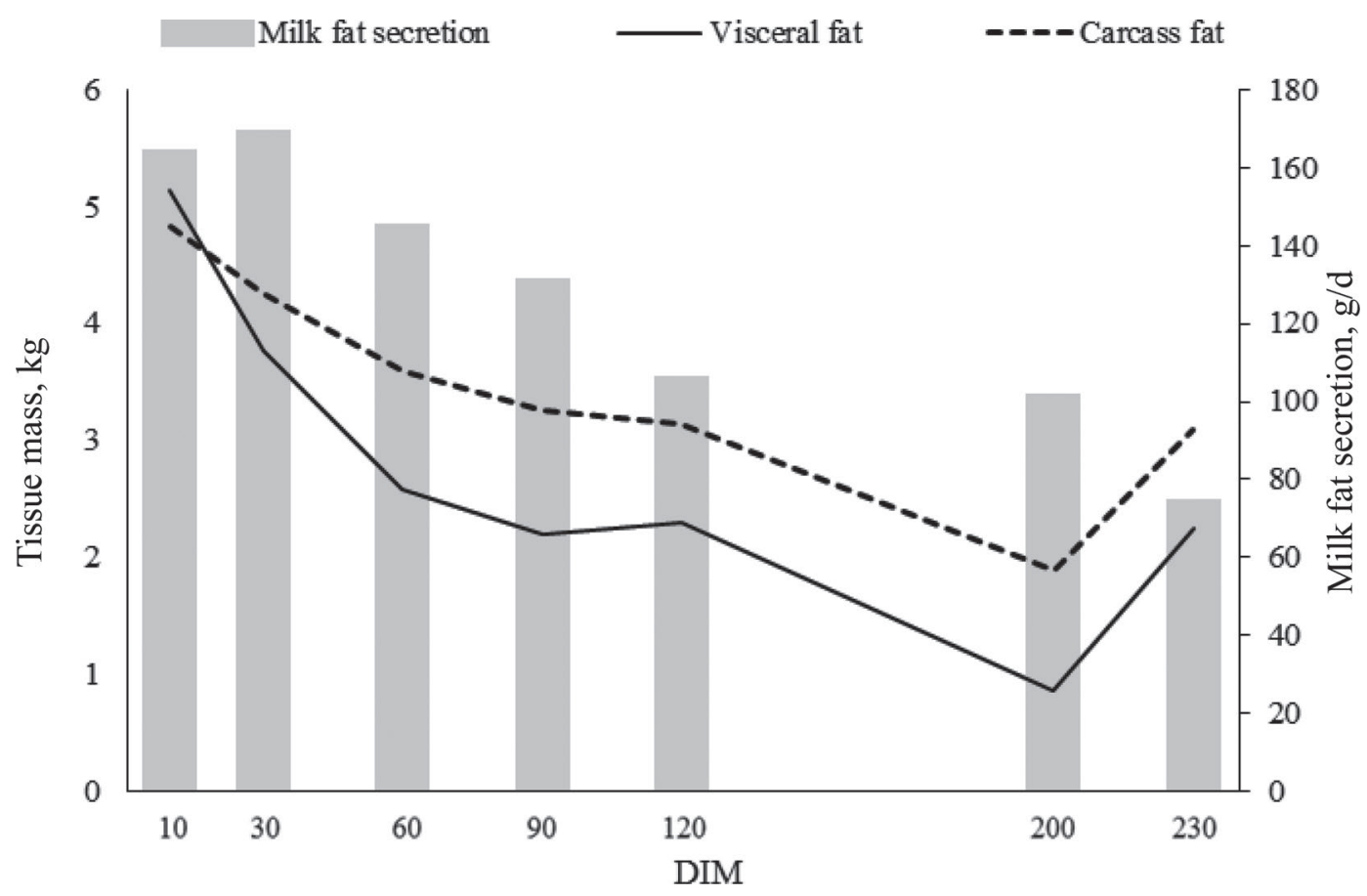

Figure 3. Changes in the mass of visceral adipose tissue and carcass adipose tissue in relation to milk fat secretion throughout a lactation. Values are averages for all the experimental goats, irrespective of feeding group. Values at 10, 30, and 60 DIM are means; values at 90 to 230 DIM are LSM. 
LIPIDS AND ENERGY STATUS IN DAIRY GOATS

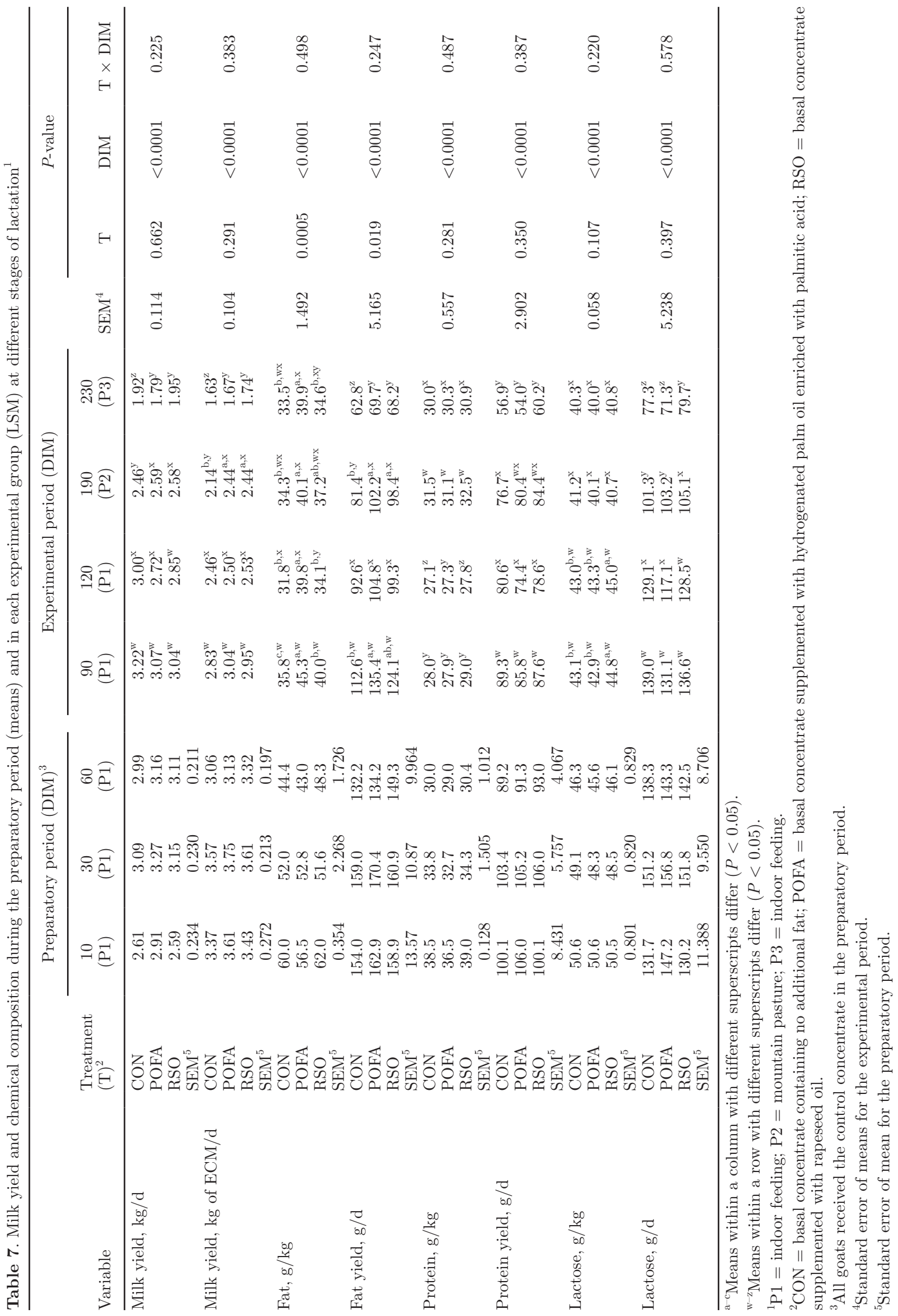


groups. Neither milk protein content nor milk protein yield was affected by dietary fat supplements. Milk lactose content gradually decreased from kidding and throughout lactation. At 90 and 120 DIM, lactose content was higher $(P<0.05)$ in milk for RSO compared with $\mathrm{CON}$ and POFA treatments.

\section{DISCUSSION}

\section{DMI and Changes in Body Lipid Mass}

The observed feed intake, expressed as total grams of DM per kilogram of BW (Table 4), is in line with Dønnem et al. (2011), who observed intakes of goats from 32.2 to $41.2 \mathrm{~g}$ of $\mathrm{DM} / \mathrm{kg}$ of BW during the period of 10 to 120 DIM with silage qualities and concentrate levels similar to those in the present experiment.

Previous reports indicate that dams become progressively capable of increasing their feed intake during the first few weeks after kidding. In spite of this, the amount eaten increases more slowly than the nutritional needs, and peak feed intake is not attained until wk 5 to 8 of lactation (Sauvant et al., 1991; Mendizabal et al., 2011). The present results (Figure 1 and Table 4) are consistent with these previous reports.

The pronounced body lipid mobilization that occurred during mountain grazing can most likely be explained by a greater energy expenditure when grazing natural pastures of variable quality and with long walking distances, as shown by Eknæs (1999). To compensate for this considerable loss of body fat, the goats had an unexpectedly high feed intake during the autumn indoor feeding period. In a similar experiment, Kharrat and Bocquier (2010) reported an adaptive behavior involving increased feed intake and intense body lipid deposition following transfer from natural rangelands to managed pastures and indoor feeding. This is also in agreement with observations in dairy cows showing higher LPL activity in AT and adipocyte size recovery during mid lactation, following underfeeding in early lactation (Chilliard, 1987). Similarly, highyielding dairy goats had higher body lipid mobilization in early lactation and higher AT LPL activity, allowing AT recovery during mid lactation, compared with lowyielding goats (Chilliard et al., 2003). Furthermore, dairy goats prioritize rebuilding of body reserves before the next reproductive cycle (Goetsch et al., 2001; Blanc et al., 2006), and pregnant goats (first month of pregnancy) had higher AT LPL activity in late lactation than goats that had not been mated (Chilliard et al., 1981). In the current study, 23 of the 30 experimental goats were mated during the autumn indoor feeding period (P3). Eighteen of those goats conceived and conception rates were not different across the feeding groups. Average mating day was at $210 \pm 7$ DIM.
Chilliard et al. (1981) estimated that about 34 Mcal could be mobilized from visceral and 18 Mcal from carcass AT, for a secretion of about $50 \mathrm{~kg}$ of milk. This is in agreement with our data (Figure 3), showing that visceral fat tissues are mobilized at about twice the speed of carcass AT depots during early lactation. Furthermore, the weight of visceral AT estimated just after kidding in the present study $(5.10 \mathrm{~kg}$ at DIM $10)$ is similar to that $(5.05 \mathrm{~kg})$ measured in 8 slaughtered late-lactating Alpine goats that had been housed indoors with hay and concentrates during the entire lactation (Chilliard et al., 1981).

Body lipid is mobilized when energy intake is insufficient to sustain lactation energy demands, thus channeling body reserves toward the mammary gland (Chilliard, 1993). In late lactation, the goats returned to a positive energy balance due to decreased milk secretion (Tables 6 and 7) and high forage intakes (Figure 1). When lactating goats are in positive energy balance, a greater part of dietary FA and de novo synthesized FA in AT are stored by AT (Chilliard et al., 2003), as seen in the indoor feeding period (200-230 DIM), when the goats deposited on average $92 \mathrm{~g}$ of body lipid/day.

It is well known that feed intake depression may occur when supplementing diets with fat (Sanz Sampelayo et al., 2007). The mechanisms by which supplemental fat sometimes depresses feed intake are still not clear but could involve effects on ruminal fermentation and gut motility, acceptability of diets containing added fat, release of gut hormones, or oxidation of fat in the liver (Allen, 2000). In the present study, the negative effect of POFA supplementation on DMI of goats was probably due to the form of presentation of lipids - free FA in POFA compared with triglycerides in RSO - which might have induced differences in the acceptability or digestive or metabolic effects of the fat sources. Indeed, a lower acceptability for calcium salts of palmitic acid compared with other lipid supplements under triglyceride form was previously shown in dairy cattle herds (Grummer et al., 1990). However, our observations disagree with a previous report of no difference in DMI when goats were supplemented with hydrogenated palm oil (Agazzi et al., 2010) and are in line with the absence of effect on DMI when goats fed a high-forage diet were supplemented with intact rapeseed (Ollier et al., 2009) or goats receiving hay diets were supplemented with different unsaturated plant oils (Martinez Marín et al., 2011).

\section{Energy Status}

From 10 to 30 DIM, body lipid stores and protein stores were reduced by 3.7 and $0.4 \mathrm{~kg}$, respectively. In the same period, BW increased by $0.9 \mathrm{~kg}$. These data 
may be explained by the concomitant loss in body lipid and increase in gut size, gut mass, and body water often observed during early lactation (Nsahlai et al., 2004). From 200 to 230 DIM, BW increased by $7.7 \mathrm{~kg}$, whereas body fat increased by only $2.6 \mathrm{~kg}$. An increase in gut DM and water due to high intake likely explains, at least in part, this difference.

Agazzi et al. (2010) observed no significant differences in BW and BCS in either the pre- or post-kidding period between goats supplemented with protected fish oil or hydrogenated palm oil. However, the fat supplements gave significantly lower values for energy balance after kidding, and the decrease in BW was numerically higher for hydrogenated palm oil compared with the control and fish oil groups. In the present experiment, POFA goats had lower levels of energy balance compared with CON and RSO goats throughout lactation. The lower silage intake by POFA goats, probably linked to the hypophagic effect of free FA and the maintenance of milk energy secretion, may explain this result.

A slight decrease in protein tissue mass was observed from 10 to 30 DIM, in agreement with Barnes and Brown (1990), who concluded that protein was mobilized to maintain milk production by Alpine goats when nutrient intake was inadequate during early lactation. Similar observations were reported in underfed early-lactating cows (Chilliard and Robelin, 1983) and in low-BCS cows presenting a higher 3-methylhistidine:creatinine ratio, an indicator of body protein mobilization, than high-BCS cows (Pires et al., 2013). The considerable body lipid mobilization during the mountain grazing period was not accompanied by a decrease in either BCS or in protein-rich tissue. This suggests that homeorhetic regulations (Chilliard, 1987) allow milk yield to be maintained at the expense of body proteins in underfed goats during early but not during late lactation.

\section{Milk Yield and Milk Composition}

Brown-Crowder et al. (2001) showed that diets supplemented with partially hydrogenated tallow in early-lactation dairy goats led to a greater milk production and greater content of milk fat. A similar response was observed with supplements of tallow, fat prills, and soybean oil (Chilliard et al., 2003). In the present experiment, however, no effect of fat supplements was observed on milk yield, whereas the POFA group displayed a higher milk fat content during the experimental period.

The reduction in milk yield observed at the end of the mountain grazing period is probably an effect of lactation stage (in accordance with the classical lactation curve in goats) and of putative energy intake limita- tions. Furthermore, in the present study, reduced milk yields could be due to competition for energy between milk synthesis and grazing (physical activity) costs.

The increase in milk fat content when supplemental fat is added to a diet is dependent on the level of fat in the diet, the productive capability of the animal, and the stage of lactation (Sanz Sampelayo et al., 2007). Milk fat content was similar for the RSO and CON groups, which is in line with previous observations on goats, in which no decrease or even an increase in milk fat content was detected when the diet was supplemented with PUFA-rich vegetable oils and with nearly all types of lipid supplements (Chilliard et al., 2003). This discrepancy in responses among species is likely due to the lower ruminal shift from the trans-11 to the trans-10 pathway in goats, combined with a lower sensitivity of the mammary lipogenesis to the antilipogenic effect of FA isomers associated with the trans-10 pathway, mainly $\mathrm{C} 18: 1$ trans -10 and $\mathrm{C} 18: 2$ trans -10 (Chilliard et al., 2014). However, the higher milk fat content in the POFA compared with RSO and CON groups observed in the present study was probably due to a lower ruminal biosynthesis of these antilipogenic FA because of a lower intake of their C18:1 and C18:2 precursors.

The proportion of the mobilized fatty acids used in milk fat synthesis is usually less than $10 \%$ but is much higher in cases of negative energy balance in cows (Bauman and Griinari, 2001) and goats (Chilliard et al., 2003). The tendency toward increased milk fat content during the grazing period, irrespective of the diet, is in line with the cited findings that negative energy balances can explain the ability to allow maintenance of fat yield despite decreases in milk yield. From 190 to 230 DIM, the total secretion of milk fat was reduced from $95 \pm 14$ to $68 \pm 13 \mathrm{~g} / \mathrm{d}$, while the goats deposited on average $95 \pm 17 \mathrm{~g} / \mathrm{d}$ in the same period. A similar response was also noted by Eknæs et al. (2006), and can be explained by the coexistence of an active lipogenesis in the mammary secretory tissue and a significant anabolic activity in the omental and perirenal AT in non-pregnant, late-lactation goats (Toral et al., 2013).

In the present experiment, milk protein content was not affected by fat supplements, in contrast to the reduction in milk protein content observed in dairy cows (Lerch et al., 2012), but our observation is consistent with other reports on goats where fat supplements did not change milk protein content (Chilliard et al., 2003; Bernard et al., 2009a; Eknæs et al., 2009; Ollier et al., 2009).

The observed positive effect of RSO at 90 and 120 DIM on lactose content is in line with previous data in mid-lactation goats showing that plant oils increase lactose content of milk (Bernard et al., 2009b). 


\section{CONCLUSIONS}

The POFA treatment increased milk fat content, whereas no difference in daily milk fat yield was observed between POFA and RSO treatments. Body lipid stores varied greatly during the lactation cycle. In early lactation (10-30 DIM), mobilization occurred at a rate of $101 \mathrm{~g} / \mathrm{d}$, decreasing thereafter until 120 DIM, when the mobilization rate intensified again during the mountain grazing period. Conversely, goats balanced their proteinous tissue weight over the lactation after a small decrease was observed postpartum. When adequate feed resources became available in late lactation, the goats presented a great ability to rebuild their fat reserves. Supplementation of a concentrate with inclusion of $8 \%$ hydrogenated palm oil or rapeseed oil did not influence these physiological and seasonal changes in body lipid stores.

\section{ACKNOWLEDGMENTS}

The authors thank the staff at the Animal Production Experimental Centre of the Norwegian University of Life Sciences for animal care and assistance with sampling procedures; Kari Eikanger (Department of Animal and Aquacultural Sciences, NMBU, Norway) for technical assistance during CT scannings and BCS and BMI measurements; Claes Gøran Fristedt (Department of Animal and Aquacultural Sciences, NMBU, Norway) for technical assistance with CT scannings; Jørgen Kongsro (Department of Animal and Aquacultural Sciences, NMBU, Norway) for developing the CT image analysis program; Irene Comi (Department of Chemistry, Biotechnology and Food Sciences, NMBU, Norway) for technical assistance during milk sampling; Tormod Ådnøy (Department of Animal and Aquacultural Sciences, NMBU, Norway) for advice regarding the statistical analysis; and Christine Leroux (UMR 1213 Herbivores, INRA, Theix, France) for valuable discussions during preparation of this paper. The Norwegian Research Council (NFR, Lysaker, Norway) and TINE BA (Oslo, Norway) financed this study, and TINE provided Milkoscan analysis free of charge.

\section{REFERENCES}

Agazzi, A., G. Invernizzi, A. Carnpagnoli, M. Ferroni, A. Fanelli, D. Cattaneo, A. Galmozzi, M. Crestani, V. Dell'Orto, and G. Savoini. 2010. Effect of different dietary fats on hepatic gene expression in transition dairy goats. Small Rumin. Res. 93:31-40. https://doi. org/10.1016/j.smallrumres.2010.04.027.

Allen, M. S. 2000. Effects of diet on short-term regulation of feed intake by lactating dairy cattle. J. Dairy Sci. 83:1598-1624.

AOAC International. 2000. Official Methods of Analysis. Vol. 1. 17th ed. Rev. 2. AOAC International, Gaithersburg, MD.
Barnes, D. M., and D. L. Brown. 1990. Protein reserves in lactating dairy goats. Small Rumin. Res. 3:19-24. https://doi. org/10.1016/0921-4488(90)90027-4.

Bauman, D. E., and J. M. Griinari. 2001. Regulation and nutritional manipulation of milk fat: Low-fat milk syndrome. Livest. Prod. Sci. 70:15-29.

Bernard, L., M. Bonnet, C. Leroux, K. J. Shingfield, and Y. Chilliard 2009a. Effect of sunflower-seed oil and linseed oil on tissue lipid metabolism, gene expression, and milk fatty acid secretion in Alpine goats fed maize silage-based diets. J. Dairy Sci. 92:6083-6094. https://doi.org/10.3168/jds.2009-2048.

Bernard, L., K. J. Shingfield, J. Rouel, A. Ferlay, and Y. Chilliard. 2009b. Effect of plant oils in the diet on performance and milk fatty acid composition in goats fed diets based on grass hay or maize silage. Br. J. Nutr. 101:213-224. https://doi.org/10.1017/ S0007114508006533.

Blanc, F., F. Bocquier, J. Agabriel, P. D'Hour, and Y. Chilliard. 2006. Adaptive abilities of the females and sustainability of ruminant livestock systems. A review. Anim. Res. 55:489-510. https://doi. org/10.1051/animres:2006040.

Brown-Crowder, I. E., S. P. Hart, M. Cameron, T. Sahlu, and A. L. Goetsch. 2001. Effects of dietary tallow level on performance of Alpine does in early lactation. Small Rumin. Res. 39:233-241. https://doi.org/10.1016/s0921-4488(00)00197-8.

Chilliard, Y. 1987. Literature survey - Body composition and lipid metabolism in adipose tissues and liver during pregnancy and lactation. 2. In the ewe and the cow. Reprod. Nutr. Dev. 27:327-398. https://doi.org/10.1051/rnd:19870301.

Chilliard, Y. 1993. Dietary fat and adipose tissue metabolism in ruminants, pigs, and rodents - A review. J. Dairy Sci. 76:3897-3931. https://doi.org/10.3168/jds.S0022-0302(93)77730-9.

Chilliard, Y., A. Ferlay, J. Rouel, and G. Lamberet. 2003. A review of nutritional and physiological factors affecting goat milk lipid synthesis and lipolysis. J. Dairy Sci. 86:1751-1770. https://doi org/10.3168/jds.S0022-0302(03)73761-8.

Chilliard, Y., and J. Robelin. 1983. Mobilization of body proteins by early lactating dairy cows measured by slaughter and $\mathrm{D}_{2} 0$ dilution techniques. Pages 195-198 in Proc. 4th Int. Symp. Protein Metabolism and Nutrition. Vol. 2. EAAP Publications/INRA Publications, Clermont-Ferrand, France.

Chilliard, Y., D. Sauvant, P. Bas, G. Pascal, and P. Morand-Fehr. 1981. Importance relative et activites metaboliques des differents tissus adipeux de la chevre laitiere. Pages 80-89 in Nutrition and Systems of Goat Feeding. P. Morand-Fehr, A. Bourbouze, and M. de Simiane, ed. INRA-ITOVIC, Tours, France.

Chilliard, Y., P. G. Toral, K. J. Shingfield, J. Rouel, C. Leroux, and L. Bernard. 2014. Effects of diet and physiological factors on milk fat synthesis, milk fat composition and lipolysis in the goat: A short review. Small Rumin. Res. 122:31-37. https://doi.org/10.1016/j. smallrumres.2014.07.014.

Dagnachew, B. S., G. Thaller, S. Lien, and T. Ådnøy. 2011. Casein SNP in Norwegian goats: additive and dominance effects on milk composition and quality. Genet. Sel. Evol. 43:31. https://doi. org/10.1186/1297-9686-43-31

Dønnem, I., A. T. Randby, and M. Eknæs. 2011. Effects of grass silage harvesting time and level of concentrate supplementation on nutrient digestibility and dairy goat performance. Anim. Feed Sci. Technol. 163:150-160. https://doi.org/10.1016/j. anifeedsci.2010.10.018

Eknæs, M., Ø. Havrevoll, H. Volden, and K. Hove. 2009. Fat content, fatty acid profile and off-flavours in goats milk-Effects of feed concentrates with different fat sources during the grazing season. Anim. Feed Sci. Technol. 152:112-122. https://doi.org/10.1016/j. anifeedsci.2009.04.006

Eknæs, M., K. Kolstad, H. Volden, and K. Hove. 2006. Changes in body reserves and milk quality throughout lactation in dairy goats. Small Rumin. Res. 63:1-11. https://doi.org/10.1016/j. smallrumres.2004.11.016.

Eknæs, M., A. Eide, T. H. Garmo, and Ø. Havrevoll. 1999. Factors affecting the milk flavour of dairy goats grazing on mountain pastures. Pages $70-72$ in Grazing and Pasture Management in the 
Nordic Countries; Proceedings from NJF Seminar no 305. Vol. 126. T. H. Garmo, ed. Nordic Association of Agricultural Scientists, Ås, Norway.

Fullerton, G. D. 1980. Fundamentals of CT tissue characterisation. Pages 125-162 in Medical Physics of CT and Ultrasound: Tissue Imaging and Characterisation. Med. Phys. Monogr. No. 6. Vol. 6. G. D. Fullerton and J. A. Zagzebski, ed. American Institute of Physics, College Park, MD.

Goetsch, A. L., G. Detweiler, T. Sahlu, R. Puchala, and L. J. Dawson. 2001. Dairy goat performance with different dietary concentrate levels in late lactation. Small Rumin. Res. 41:117-125. https://doi. org/10.1016/s0921-4488(01)00212-7.

Grummer, R. R., M. L. Hatfield, and M. R. Dentine. 1990. Acceptability of fat supplements in four dairy herds. J. Dairy Sci. 73:852-857.

Gundersen, H. J. G., T. F. Bendtsen, L. Korbo, N. Marcussen, A. Moller, K. Nielsen, J. R. Nyengaard, B. Pakkenberg, F. B. Sorensen, A. Vesterby, and M. J. West. 1988. Some new, simple and efficient stereological methods and their use in pathological research and diagnosis-Review article. APMIS 96:379-394.

Inglingstad, R. A., S. Skeie, G. E. Vegarud, T. G. Devold, Y. Chilliard, and M. Eknæes. 2017. Feeding a concentrate rich in rapeseed oil improves fatty acid composition and flavor in Norwegian goat milk. J. Dairy Sci. 100:7088-7105. https://doi.org/10.3168/ jds.2016-12383.

Kharrat, M., and F. Bocquier. 2010. Impact of indoor feeding at late lactation stage on body reserves recovery and reproductive performances of Baladi dairy goats fed on pastoral system. Small Rumin. Res. 90:127-134. https://doi.org/10.1016/j. smallrumres.2010.02.007.

Kirsten, W. J., and G. U. Hesselius. 1983. Rapid, automatic, highcapacity Dumas determination of nitrogen. Microchem. J. 28:529547. https://doi.org/10.1016/0026-265x(83)90011-5.

Lerch, S., A. Ferlay, D. Pomies, B. Martin, J. A. A. Pires, and Y. Chilliard. 2012. Rapeseed or linseed supplements in grass-based diets: Effects on dairy performance of Holstein cows over 2 consecutive lactations. J. Dairy Sci. 95:1956-1970. https://doi.org/10.3168/ jds.2011-4575.

Littell, R. C., P. R. Henry, and C. B. Ammerman. 1998. Statistical analysis of repeated measures data using SAS procedures. J. Anim. Sci. 76:1216-1231.

Malkomesius, P., and K. Nehring. 1951. Chemische Untersuchung von Futtermitteln. in Handbuch der landwirtschaftlichen Versuchs-und Untersuchungsmethodikt (Methodenbuch), Band III. Herrmann R., ed. Neumann Verlag, Berlin, Germany.

Martinez Marín, A. L., P. Gomez-Cortes, A. G. G. Castro, M. Juarez, L. M. P. Alba, M. P. Hernandez, and M. A. de la Fuente. 2011. Animal performance and milk fatty acid profile of dairy goats fed diets with different unsaturated plant oils. J. Dairy Sci. 94:53595368. https://doi.org/10.3168/jds.2011-4569.

Mendizabal, J. A., R. Delfa, A. Arana, and A. Purroy. 2011. Body condition score and fat mobilization as management tools for goats on native pastures. Small Rumin. Res. 98:121-127. https://doi. org/10.1016/j.smallrumres.2011.03.029.

Morand-Fehr, P., V. Fedele, M. Decandia, and Y. Le Frileux. 2007. Influence of farming and feeding systems on composition and quality of goat and sheep milk. Small Rumin. Res. 68:20-34. https://doi. org/10.1016/j.smallrumres.2006.09.019.

Ngwa, A. T., L. J. Dawson, R. Puchala, G. Detweiler, R. C. Merkel, I. Tovar-Luna, T. Sahlu, C. L. Ferrell, and A. L. Goetsch. 2007. Urea space and body condition score to predict body composi- tion of meat goats. Small Rumin. Res. 73:27-36. https://doi. org/10.1016/j.smallrumres.2006.10.014.

Nsahlai, I. V., A. L. Goetsch, J. Luo, Z. B. Johnson, J. E. Moore, T. Sahlu, C. L. Ferrell, M. L. Galyean, and F. N. Owens. 2004. Metabolizable energy requirements of lactating goats. Small Rumin. Res. 53:253-273. https://doi.org/10.1016/j.smallrumres.2004.04.007.

Ollier, S., C. Leroux, A. de la Foye, L. Bernard, J. Rouel, and Y. Chilliard. 2009. Whole intact rapeseeds or sunflower oil in highforage or high-concentrate diets affects milk yield, milk composition, and mammary gene expression profile in goats. J. Dairy Sci. 92:5544-5560. https://doi.org/10.3168/jds.2009-2022.

Onetti, S. G., and R. R. Grummer. 2004. Response of lactating cows to three supplemental fat sources as affected by forage in the diet and, stage of lactation: A meta-analysis of literature. Anim. Feed Sci. Technol. 115:65-82. https://doi.org/10.1016/j. anifeedsci.2004.02.009.

Otaru, S. M., A. M. Adamu, O. W. Ehoche, and H. J. Makun. 2011. Effects of varying the level of palm oil on feed intake, milk yield and composition and postpartum weight changes of Red Sokoto goats. Small Rumin. Res. 96:25-35. https://doi.org/10.1016/j. smallrumres.2010.11.004.

Pires, J. A. A., C. Delavaud, Y. Faulconnier, D. Pomies, and Y. Chilliard. 2013. Effects of body condition score at calving on indicators of fat and protein mobilization of periparturient Holstein-Friesian cows. J. Dairy Sci. 96:6423-6439. https://doi.org/10.3168/ jds.2013-6801.

Rabiee, A. R., K. Breinhild, W. Scott, H. M. Golder, E. Block, and I. J. Lean. 2012. Effect of fat additions to diets of dairy cattle on milk production and components: A meta-analysis and metaregression. J. Dairy Sci. 95:3225-3247. https://doi.org/10.3168/ jds.2011-4895.

Sanz Sampelayo, M. R., Y. Chilliard, P. Schmidely, and J. Boza. 2007. Influence of type of diet on the fat constituents of goat and sheep milk. Small Rumin. Res. 68:42-63. https://doi.org/10.1016/j. smallrumres.2006.09.017.

Sauvant, D., P. Morand-Fehr, and S. Giger-Reverdin. 1991. Dry matter intake of adult goats. Pages $25-36$ in Goat Nutrition. P. Morand-Fehr, ed. Pudoc, Wageningen, the Netherlands.

Shingfield, K. J., Y. Chilliard, V. Toivonen, P. Kairenius, and D. I. Givens. 2008. Trans fatty acids and bioactive lipids in ruminant milk. Adv. Exp. Med. Biol. 606:3-65.

Tanaka, T., N. Akaboshi, Y. Inoue, H. Kamomae, and Y. Kaneda. 2002. Fasting-induced suppression of pulsatile luteinizing hormone secretion is related to body energy status in ovariectomized goats. Anim. Reprod. Sci. 72:185-196. https://doi.org/10.1016/s03784320(02)00091-x.

Teh, T. H., L. T. Trung, Z. H. Jia, T. A. Gipson, K. B. Ogden, and T. F. Sweeney. 1994. Varying amounts of rumen-inert fat for high producing goats in early lactation. J. Dairy Sci. 77:253-258.

Toral, P. G., L. Bernard, C. Delavaud, D. Gruffat, C. Leroux, and Y. Chilliard. 2013. Effects of fish oil and additional starch on tissue fatty acid profile and lipogenic gene mRNA abundance in lactating goats fed a diet containing sunflower-seed oil. Animal 7:948-956. https://doi.org/10.1017/S1751731113000049.

Van Soest, P. J., J. B. Robertson, and B. A. Lewis. 1991. Methods for dietary fiber, neutral detergent fiber, and nonstarch polysaccharides in relation to animal nutrition. J. Dairy Sci. 74:3583-3597.

Wolfinger, R. 1996. Heterogeneous variance-covariance structures for repeated measures. J. Agric. Biol. Environ. Stat. 1:205-230. 